\title{
理学療法の臨床経験の違いが目標設定の 重要項目に及ぼす影響
}

\author{
Influences of Clinical Experience on the Focuses of Goal-setting in Physical Therapy
}

\section{貞清 香織 ${ }^{1)}$ 貞清 秀成 ${ }^{2)}$ 石坂 正大 $^{1)}$ 上田 清史 $^{3)}$ 久保 晃 ${ }^{1)}$}

KAORI SADAKIYO, Msc, RPT ${ }^{1)}$, HIDENARI SADAKIYO, Msc, RPT ${ }^{2)}$, MASAHIRO ISHIZAKA, PhD, RPT ${ }^{1)}$, KIYOSHI UEDA, RPT ${ }^{3)}$, AKIRA KUBO, PhD, RPT ${ }^{1)}$

\footnotetext{
${ }^{1)}$ Department of Physical Therapy, School of Health Sciences, International University of Health and Welfare: 2600-1 Kitakanemaru, Ohtawara-shi, Tochigi 324-8501, Japan TEL+81287-24-3000 E-mail: uenishi@iuhw.ac.jp

${ }^{2)}$ Marronier Daycare Service, Otawara Comprehensive Homebased Care Center

${ }^{3)}$ Department of Rehabilitation, International University of Health and Welfare Hospital
}

Rigakuryoho Kagaku 32(6): 889-892, 2017. Submitted Jun. 27, 2017. Accepted Aug. 1, 2017.

\begin{abstract}
Purpose] To clarify whether the focuses of goal-setting for individual clients in physical therapy vary depending on therapists' clinical experience, this study compared such focuses between students of a physical therapist training school (student PTs) and professional physical therapists (professional PTs). [Subjects and Methods] A total of 50 professional PTs (mean length of clinical experience: $3.7 \pm 2.1$ years), who worked in facilities belonging to the study university, and 54 student PTs in their third or fourth year at the Department of Physical Therapy of the same university, who consented to cooperate with the study, were involved. [Results] The professional and student PTs tended to attach importance to the 'previous lives' and 'activities' of patients, respectively, when setting goals for them. [Conclusion] The focuses of goal-setting varied between the professional and student PTs. There were no differences related to the school year, suggesting that such a variation was associated with clinical experience as a PT. Key words: goal-setting, clinical experience, clinical training
\end{abstract}

要旨：〔目的〕理学療法士養成校の学生と理学療法士（以下：PT）が対象者の目標設定する際, 何を重要視している かを調査し, 臨床経験の違いが目標設定の重要項目に影響を及ぼしているかを検討した。〔対象と方法〕本大学関連 施設に勤める PT50 名（経験年数 $3.7 \pm 2.1$ 年）と本学理学療法学科 3 年生, 4 年生のうち協力の得られた学生（以下: 学生）54名とした。〔結果〕PT は「病前の生活」を, 学生は「活動面」を重要視する傾向がみられた。〔結語〕PT と学生では目標設定の際に, 重要視する項目が異なり, 学年間ではその項目に変化はなく, PT として臨床現場を経 験することで変化していくことが示唆された.

キーワード：目標設定, 臨床経験, 臨床実習

1) 国際医療福祉大学 保健医療学部 理学療法学科 : 栃木県大田原市北金丸 2600-1 ( ₹ 324-8501) TEL 0287-24-3000

2) おおたわら在宅総合ケアセンター マロニエデイケアサービス

3) 国際医療福祉大学病院 リハビリテーション室

受付日 2017 年 6 月 27 日 受理日 2017 年 8 月 1 日 


\section{I. はじめに}

全国の理学療法養成校は 258 校を数え 1), 平成 29 年 3 月も 12,388 人が理学療法士の資格を取得している ${ }^{2)}$. 理学療法士養成のカリキュラムにおい臨床実習は重要な 科目の 1 つである。臨床実習では学内教育で習得した知 識・技術を臨床現場で統合するだけではなく，専門職に 必要な適切な行動・態度を修得することが求められる。 その進め方は, 臨床実習施設や指導者に委ねられている が, 対象者を通じて, 理学療法評価, 問題点の抽出, 目 標設定, 治療の理学療法の過程を学ぶことは共通して いる.

理学療法士にとって, 対象者の状態を評価しながら治 療計画を立案することは重要である。なかでも対象者の 目標設定はプログラム実施の前提条件となり, 高度な目 標を設定することは対象者の心理的負担も大きくなりモ チベーションに関わってくる. 現在の状態を正確に判断 し，どのように変化するか，変えることができるか否か 科学的根拠をもって判断する必要がある.

目標設定は, 現在の状態, 対象者の価值観, 変化の可 能性によって決定されるため, 重症度, 疾病の経過, 運 動学習能力, 環境の視点から病態の状態と変化を検証す る必要がある3)。また，これまでの生活や身体機能が目 標に影響を及ぼす可能性も考える必要がある。

目標を設定するには，正確な身体機能や活動の評価, 予後の知識, 臨床経験が必要である4) といわれているが, 学生が目標設定について学内で学ぶ機会は少ないのが現 状である。理学療法評価や臨床実習関連の書籍には，患 者情報や検査・測定結果を統合と解釈することにより， 問題点を抽出して，目標の設定とプログラムの立案を行 うと記載されている5,6). 臨床経験が少ない臨床実習学 生は, 予後予測が未熟であり患者 HOPEが予後予測の 範疇から外れていても, 非現実的なものを目標に設定す る傾向がある。また, 評価から動作の制限因子を抽出し た後，動作を観察して評価結果を検証することが多くみ られ，身体機能面を中心に目標を考える傾向もみられ る. 今後の生活を考える上では，身体機能だけではなく 個人・環境因子を組み込んだ活動や参加を目標に掲げる ことが重要である.

このように対象者の目標設定には, 臨床経験の違いが 関与する可能性があるが, 実際にどの情報や評価を重要 視して目標を設定しているかは明らかになっていない. 臨床現場の理学療法士と臨床実習学生が目標設定時に重 要視する項目を調査することで, 理学療法士の卒前・卒 後教育の一助となる可能性がある.

そこで本研究は, 臨床実習学生と臨床現場の理学療法 士が対象者の目標設定する際, 何を最重要視して目標を 設定しているかを調査し, 臨床経験の違いが影響を及ぼ しているか検討する.

\section{II. 対象と方法}

\section{1. 対象}

対象は，本学近隣にある大学関連施設（小览施設を除 く）に勤める理学療法士（以下, PT） 50 名（平均経験 年数士標準偏差 : $3.7 \pm 2.1$ 年) と平成 26 年度本学理 学療法学科 3 年生, 4 年生のうち協力の得られた学生 (以 下，学生） 54 名とした。対象学生は，関連施設内外で 実習を行った 3 年生 29 名（男性 16 名, 女性 13 名）と 4 年生 25 名（男性 11 名, 女性 14 名）であった。 3 年 生は平成 26 年 8 月上旬から 9 月中旬にかけて実施した 3 週間の評価実習後, 4 年生は平成 26 年度の総合臨床 実習 6 週間を 2 期終了した後に実施した。対象者には, 研究の主旨, 内容, 研究で得られた結果は目的以外に使 用しないこと，成績評価に一切関わらないことを十分に 説明し同意を得た。本研究は, 本大学倫理審査委員会の 承認を得た（14-Io-52）.

\section{2. 方法}

対象者には，自由記載のアンケートにより目標設定に 最も重要視する評価および情報について 1 項目挙げるよ うに依頼した。得られた回答を同様の項目にまとめた。 対象者の現在の心身機能を重要視する回答を「身体機能 面」にまとめ, 対象者の現在の歩行, 基本動作, 日常生 活動作（以下, ADL) 等を重要視する回答を「活動面」 とした。これらは，ICFの分類に基づいて分類した。対 象者の病前の状況, ADL と回答しているものを「病前 の生活」, 対象者の主訴やHOPE，想いは「主訴 . HOPE」にまとめた。年齢や個人の社会的背景の回答を 「個人面」, 物的, 人的, 社会的環境を「環境面」にまと めた。 また, 学生は学年ごと, PT は経験年数（1３年 29 名を新人群, 4 年目以降 21 名を指導者群）の 4 群に 分け，同様の回答をまとめて割合を算出した.

統計解析は経験年数による違いを明らかにするために, 期待度数を評価実習後の 3 年次学生の回答の割合とし, その他の群を出現度数とした $\chi^{2}$ 適合度検定を行った。 有意水準は $5 \%$ とした. PTにおいては所属している施 設（急性期，回復期，生活期）に分けて集計した。

\section{III. 結 果}

無回答の学生 1 名を除く 103 名（PT：50 名, 学生： 53 名）を有効回答とした。分類したものを $\mathrm{PT}$ ，学生の 経験年数, 学年ごとにまとめた（表 1)。学生は「活動面」 が一番多く,「主訴・HOPE」,「身体機能面」の順であっ た。学年別では, 評価実習後の 3 年次, 総合臨床実習後 の 4 年次ともに「活動面」,「主訴・HOPE」,「身体機能 面」の順であった。

$\mathrm{PT}$ の結果は,「病前の生活」が一番多く 17 名であり, 
表 1 経験年数, 学年ごとの重要項目の比較

\begin{tabular}{llcccccccc}
\hline & & & 病前の生活 & 身体機能面 & 活動面 & 主訴・HOPE & 個人面 & 環境面 \\
\hline PT & 指導者群 * & $(\mathrm{n}=21)$ & $7(33.3)$ & $2(9.5)$ & $0(0.0)$ & $6(28.6)$ & $1(4.8)$ & $5(23.8)$ \\
& 新人群 $*$ & $(\mathrm{n}=29)$ & $10(34.5)$ & $4(13.8)$ & $6(20.7)$ & $3(10.3)$ & $2(6.9)$ & $4(13.8)$ \\
学生 & 4 年生 & $(\mathrm{n}=24)$ & $2(8.3)$ & $5(20.8)$ & $8(33.3)$ & $6(25.0)$ & $1(4.2)$ & $2(8.3)$ \\
& 3 年生 & $(\mathrm{n}=29)$ & $2(6.9)$ & $5(17.2)$ & $11(37.9)$ & $8(27.6)$ & $1(3.8)$ & $2(6.9)$ \\
\hline
\end{tabular}

単位：名 $(\%)$. * : p $<0.05 . \chi^{2}$ 適合度検定.

表 2 PT の所属施設ごとの重要項目の比較

\begin{tabular}{lccccccc}
\hline & & 病前の生活 & 身体機能面 & 活動面 & 主訴 · HOPE & 個人面 & 環境面 \\
\hline 急性期 & $(\mathrm{n}=28)$ & 12 & 5 & 2 & 4 & 3 & 2 \\
回復期 & $(\mathrm{n}=12)$ & 3 & 1 & 3 & 2 & 0 & 3 \\
生活期 & $(\mathrm{n}=10)$ & 2 & 0 & 1 & 3 & 0 & 4 \\
\hline
\end{tabular}

単位：名.

次に「主訴・HOPE」「環境面」が多かった。臨床経験 の比較では, 新人群, 指導者群ともに「病前の生活」が 一番多く, 新人群は次に「活動面」,「身体機能面」,「環 境面」の順番であった。指導者群は次に「主訴・ HOPE」,「環境面」の順番であった. 3 年次の回答の割 合に比べ, 4 年次は差がみられなかったが, 新人群と指 導者群の回答は出現率に差があった.

また，所属施設による分類において，急性期は「病前 の生活」が一番多く, 回復期は「病前の生活」,「活動面」, 「環境面」が同数であった，生活期においては，「環境面」 「主訴・HOPE」の順であった（表 2).

\section{IV. 考 察}

本研究では, 臨床現場の PT と理学療法士養成校の学 生を対象に目標設定の際に, 重要視する項目を調査し た. その結果, 臨床現場の PT は対象者の病前の生活, ADL を含む「病前の生活」を, 学生は「動作」や「現 在の ADL」等の「活動面」を最も重視しており, 違い がみられた。また，PTは学生とは違い退院後の物理的, 人的環境面にも着目し, 目標を設定していた。学生は目 の前にいる対象者の状態を重視するが, PT は対象者の 現状だけではなく，過去や未来にも目を向けて目標を設 定していた，学生と臨床現場との違いは単に経験量の違 いだけではなく, 患者を見る視点, 障害の経過や予後の 理解などの質的な違いがある3)といわれているため, このような結果になったと考える。

また, PT の臨床経験の違いでは経験年数の少ない PT は, 対象者の活動, 身体機能に目を向けている割合が多 く, 経験年数が多くなるとその傾向が少なくなることが 明らかになった。学生, 新人 $\mathrm{PT}$, 熟練した PTの問題 解決過程の差異を比較した研究では, 学生は身体機能,
検査結果, 疾患名から解釈するが, 熟練者はこれまで担 当した患者とイメージを重ねて問題解決をする傾向があ るといわれている7). 本研究においても経験年数が長く なると様々な対象者や病期を経験するため, 視点が変化 し，違いがみられた可能性が考えられる。

$\mathrm{PT}$ の所属施設による比較では, 病期によって重要視 している点に異なる傾向がみられた，急性期では，「病 前の生活」に次いで「身体機能面」が多くなっている。 急性期医療における PT の役割に生命維持への寄与，全 身状態の安定化, 安全な早期離床の促進がある3)こと から, 現在の身体機能面を重視してリスク管理を中心に 理学療法を展開していることが考えられる。回復期にお ける PT は, 機能回復や自宅退院に向け基本動作能力を

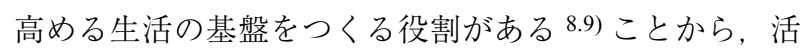
動面や退院先の環境に着目する結果となったといえる. 生活期においては生活機能の向上・維持や QOL の高い 生活の支援などが PT の役割となる 10) ため, 対象者の HOPEや想い, 生活環境を重要視する結果となったとい える。しかし, 病期により調査した人数に違いがみられ ることから, 今後は対象者を増やして検討していく必要 がある. 理学療法士の役割は病期により異なるため, 目 標も変わってくる 7.9). そのため目標をどこに設定する かにより重視する項目が異なってくる可能性がある. 目 標そのものをどこに設定し, 理学療法を行っているか調 査する必要があると考える。

学生の結果より, 評価実習を経験した 3 年次の学生と 臨床実習を経験した 4 年次の学生は類似する結果であっ たことから，限られた期間で症例を担当する実習では， 過去や未来を考えた目標設定が難しい傾向があることが 示唆された。熟練者は知覚経験から形成されたイメージ を元に目の前の問題を解決していく7)ため, 現場経験 の少ない学生では変化しなかったと考える. 
卒前・卒後教育を一連でみると，現状の対象者を中心 に考えて目標を設定していたのが, 臨床現場に出て 3 年 程度経験することで対象者全体を把握して目標を設定す るようになるといえる。これは学生では形成されなかっ たイメージが臨床現場での経験で形成されていく過程を 示しているといえる.

学校教育においては, 学内で対象者の現在の状況を検 査・評価することの重要性とともに, 目標の設定や対象 者の背景にも着目することを学ぶ機会を設ける必要があ ると考える。また，臨床実習で学生を指導する場合，指 導する PT と学生の考えに相違があることを念頭におき, 学生が対象者のどこに着目して目標を掲げているか確認 しながら指導する必要があると考える。

本研究では, 臨床現場の PT と理学療法士養成校の本 学学生は目標設定の際に, 重要視する項目が異なり, 学 生の実習ではその項目に変化はなく臨床現場で経験して いくことで変化していくことが明らかになった。

研究の限界として, 1 つ目は学生間の比較において, 限られた担当症例に対しての目標設定になるため, 偏り がでている可能性があることが挙げられる，今回学生の 実習地，担当症例についての調査を行っていないが，実 習先や担当症例による比較や同じ症例を提示して目標を 設定するなど，条件を統一して今後検討する必要がある と考える．2つ目に目標設定の期間を統一していない点 が挙げられる。目標設定の際, 短期, 長期目標など時期 や期限を設定するが，今回は行っていない．目標設定の 時期により着目する項目が変わる可能性が考えられるた め, 今後は時期も設定し検討する必要があると考える.

3つ目にPTの現在勤めている施設のみ調査した点で ある，経験年数だけではなく，異動の経験も関与する可 能性が考えられることから, 調査する必要があると考え る. 最後に今回調査した本学関連施設に勤務するPTの 出身学校に偏りがある点である。本学の卒業生が 9 割以 上占めているため, 特有の傾向を示している可能性が考
えられる。また，実習指導者として学生に影響を及ぼし ている可能性もあるため, 対象範囲を広げて調査する必 要である.

今回は PTのみの調査となっているが，職種間を比較 することでチームアプローチの一助となると可能性があ ると考える。臨床現場で活かすためにも看護師, 作業療 法士, 言語聴覚士, ケアマネージャーなど他の職種につ いても今後調査していく.

\section{引用文献}

1)（公社）日本理学療法士協会：理学療法士養成校一覧. http://www.japanpt.or.jp/general/aim/training/ (閲覧日 2017 年 6月7日).

2) 厚生労働省：国家試験合格発表. 第52回理学療法士国家 試験及び第 52 回作業療法士国家試験の合格発表につい て. http://www.mhlw.go.jp/general/sikaku/successlist/2017/ siken08_09/about.html（閲覧日2017年6月9日）.

3) 内山 靖: 脳卒中の病態評価と解釈による理学療法士 のゴール設定一急性期から回復期. 理学療法ジャーナル, 2010, 44: 115-121.

4) 上田 敏: ゴール設定をどう考えるか一目標指向的アプロー チを中心に一. 理学療法ジャーナル, 1992, 26: 432-435.

5) 理学療法科学学会 (編) : 実習の達人, 第4版. アイペック, 東京, 2009, pp4-8.

6) 齋藤昭彦 (編) : よくわかる理学療法の検査 - 測定 - 評価. 秀和システム, 東京, 2013, pp316-318.

7) 中川法一(編) : セラピスト教育のためのクリニカル・クラー クシップのすすめ。 三輪書店，東京，2007, pp43-47.

8) 丹羽義明：理学療法実習生に対する脳卒中のゴール設定指 導. 理学療法ジャーナル, 2010, 44: 131-136.

9) 松木秀行：回復期リハビリテーション一チームに扔ける動き 方一. 回復期リハビリテーション病棟における理学療法士 の役割. MEDICAL REHABILITATION, 2013, 162: 46-52.

10) 岩田 篤: 慢性期の理学療法一目標設定と治療・介入効 果. 慢性期の概念と理学療法の役割. 理学療法ジャーナル, 2015, 49: 591-598. 